Manuscript ID: BRES-D-16-00731 (revised version)

\title{
Behavioral and pharmacological phenotypes of brain-specific diacylglycerol kinase $\delta$-knockout mice
}

Takako Usuki*, Tamae Takato*, Qiang Lu*, Hiromichi Sakai*, Kana Bando ${ }^{\dagger}$, Hiroshi Kiyonari $^{\dagger}$ and Fumio Sakane*§

*Department of Chemistry, Graduate School of Science, Chiba University, 1-33 Yayoi-cho, Inage-ku, Chiba 263-8522, Japan

${ }^{\dagger}$ Animal Resource Development Unit and Genetic Engineering Team, Riken Center for Life Science Technologies, 2-2-3, Minatojima, Minami-machi, Chuo-ku, Kobe 650-0047, Japan

${ }^{\S}$ To whom correspondence should be addressed. Department of Chemistry, Graduate School of Science, Chiba University, 1-33 Yayoi-cho, Inage-ku, Chiba 263-8522, Japan. TEL/FAX: +81-43-290-3695; E-mail: sakane@faculty.chiba-u.jp

Running Title: OCD-like behavior of DGK $\delta$-KO mice

\section{Keywords}

Diacylglycerol kinase; Phosphatidic acid; Obsessive-compulsive disorder; Fluoxetine; Neurite

\footnotetext{
Abbreviations pentylenetetrazol; SSRI, selective serotonin reuptake inhibitor

DGK, diacylglycerol kinase; KO, knockout; OCD, obsessive-compulsive disorder; PTZ, 


\section{Abstract}

Diacylglycerol kinase (DGK) is a lipid-metabolizing enzyme that phosphorylates diacylglycerol to produce phosphatidic acid. Previously, we reported that the $\delta$ isozyme of DGK was abundantly expressed in the mouse brain. However, the functions of DGK $\delta$ in the brain are still unclear. Because conventional DGK $\delta$-knockout $(\mathrm{KO})$ mice die within 24 hours after birth, we have generated brain-specific conditional DGK $\delta$-KO mice to circumvent the lethality. In the novel object recognition test, the number of contacts in the DGK $\delta-\mathrm{KO}$ mice to novel and familiar objects was greatly increased compared to the control mice, indicating that the DGK $\delta-\mathrm{KO}$ mice showed irrational contacts with objects such as compulsive checking. In the marble burying test, which is used for analyzing obsessive-compulsive disorder (OCD)-like phenotypes, the DGK $\delta$-KO mice buried more marbles than the control mice. Additionally, these phenotypes were significantly alleviated by the administration of an OCD remedy, fluoxetine. These results indicate that the DGK $\delta$-KO mice showed OCD-like behaviors. Moreover, the number of long axon/neurites increased in both DGK $\delta$-KO primary cortical neurons and DGK $\delta$-knockdown neuroblastoma Neuro-2a cells compared to control cells. Conversely, overexpression of DGK $\delta$ decreased the number of long axon/neurites of Neuro-2a cells. Taken together, these results strongly suggest that a deficiency of DGK $\delta$ induces OCD-like behavior through enhancing axon/neurite outgrowth. 


\section{Introduction}

Diacylglycerol kinase (DGK) is a lipid-metabolizing enzyme that phosphorylates diacylglycerol to produce phosphatidic acid. Diacylglycerol and phosphatidic acid act as lipid second messengers in a wide variety of biological processes in mammalian cells (English, 1996; Exton, 1994; Hodgkin et al., 1998). Thus, DGK plays a pivotal role in various intracellular signaling pathways by regulating diacylglycerol and phosphatidic acid concentrations.

DGK represents a large enzyme family (Goto et al., 2006; Merida et al., 2008; Sakane et al., 2007; Topham and Epand, 2009). Ten DGK isozymes ( $\alpha, \beta, \gamma, \delta, \eta, \kappa, \varepsilon, \zeta$, 1 , and $\theta$ ) have been identified and classified into five subtypes based on their structural features. The type II DGK (Sakai and Sakane, 2012) comprises $\delta$ (Sakane et al., 1996), $\eta$ (Klauck et al., 1996), and $\kappa$ (Imai et al., 2005). Moreover, alternative splicing products of DGK $\delta(\delta 1$ and $\delta 2)$ (Sakane et al., 2002) and DGK $\eta(\eta 1$ and $\eta 2)$ (Murakami et al., 2003) have been identified. All of the type II DGK isoforms possess a pleckstrin homology domain at their N-termini and a separate catalytic region, and DGKs $\delta 1, \delta 2$, and $\eta 2$, but not DGK $\eta 1$, contain a sterile $\alpha$-motif domain at their C-termini. DGK $\delta 2$ specifically contains the Pro-rich 52 residues extending from the N-terminus (Sakane et al., 2002).

A tumor-promoting phorbol ester, 12-O-tetradecanoylphorbol 13-acetate, induces the phosphorylation, oligomer-monomer conversion and translocation to the plasma membrane of DGK $\delta 1$ (Imai et al., 2002; Imai et al., 2004; Sakane et al., 2002). DGK $\delta 1$ translocates from the cytoplasm to the plasma membrane via the $\mathrm{PH}$ and $\mathrm{C} 1$ domains in response to high glucose levels (Takeuchi et al., 2012). DGK $\delta$ forms oligomeric (at least tetrameric) structures in vitro and in vivo and that the SAM domain plays a critical role in oligomer formation (Harada et al., 2008; Imai et al., 2002; Knight et al., 2010; Sakane et al., 2002).

Based on the analysis of DGK $\delta$-knockout (KO) mice, it has recently been 
reported that DGK $\delta$ regulates the epidermal growth factor receptor pathway in epithelial cells of the lungs and skin (Crotty et al., 2006) and insulin receptor signaling in skeletal muscle (Chibalin et al., 2008; Miele et al., 2007) by modulating PKC activity.

In addition to being expressed in skeletal muscle cells (Chibalin et al., 2008; Miele et al., 2007; Sakai et al., 2014; Sakane et al., 1996), DGK $\delta$ was abundantly expressed in mouse brains (Usuki et al., 2015). DGK $\delta 2$, but not DGK $\delta 1$, was highly expressed in layers II-VI of the cerebral cortex, hippocampus, dentate gyrus, the mitral cell, granule cell and glomerular layers of the olfactory bulb and the granule cell layer of the cerebellum in one- to 32-week-old mice (Usuki et al., 2015). DGK $\delta 2$ was expressed just after birth, and its expression levels dramatically increased from one to four weeks. Moreover, DGK $\delta$ has been reported to be related to neurological disorders (Leach et al., 2007). A female patient with a de novo balanced translocation, 46,X,t(X;2)(p11.2;q37)dn, exhibited seizures, capillary abnormality, developmental delay, infantile hypotonia and obesity (Leach et al., 2007). However, the functions of DGK $\delta$ in neurological disorders are still unclear.

Because conventional $\mathrm{KO}$ mice die within $24 \mathrm{~h}$ of birth, it is difficult to analyze higher brain functions using them. Therefore, in this study, we generated brain-specific conditional DGK $\delta$-KO mice and used these mice to perform behavioral and pharmacological tests. 


\section{Results}

\subsection{Generation of brain-specific DGK $\delta$-deficient mice}

To investigate a potential role for DGK $\delta$ in the brain in vivo, we generated a brain-specific DGK $\delta$ conditional allele targeting exon 9 (Suppl. Fig. 1A), circumventing the immediate postnatal lethality associated with the germline deletion of DGK $\delta$ in mice (Crotty et al., 2006). PCR screening of tail-derived genomic DNA showed that LoxP sites were placed flanking exon 9 of $D G K \delta$ (Suppl. Fig. 1B). Moreover, we confirmed that the DGK $\delta 2$ protein, which was expressed in the control mice $\left(\right.$ cre $^{-/}: \operatorname{lox} \mathrm{P}^{+/+}$), was not detected in the brain of the conditional DGK $\delta$-KO mice

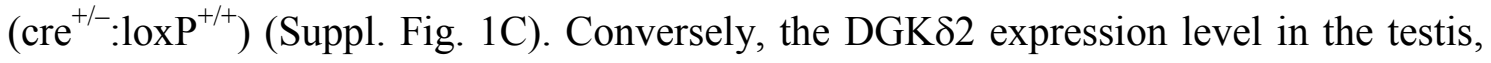
in which the protein was strongly expressed in wild-type mice (Shionoya et al., 2015; Usuki et al., 2015), was almost the same as that of the control littermates. We verified that deleting DGK $\delta$ did not significantly affect protein expression of other DGK isozymes $(\alpha, \beta, \gamma, \eta, \kappa, \varepsilon, \zeta, \imath$ and $\theta)$ in the brain (Suppl. Fig. 2).

The brain-specific DGK $\delta$-KO mice grew normally and were reproductively active. A previous report (Leach et al., 2007) demonstrated that a female patient lacking the DGK $\delta$ gene exhibited seizures. A potential seizure phenotype in mutant mice was investigated by a seizure-susceptibility study using a subthreshold dose of pentylenetetrazol (PTZ). However, no significant difference in susceptibility to PTZ-induced seizures was detected (Suppl. Fig. 3). Moreover, we performed the open field test (for activity and anxiety abnormalities) (Suppl. Fig. 4), the elevated plus-maze test (anxiety abnormality) (Suppl. Fig. 5), the sociability test (Suppl. Fig. 6), the Barnes maze test (cognitive defects) (Suppl. Fig. 7), the cotton bud biting test (aggressiveness) (Suppl. Fig. 8), and the tail suspension test (anti-depressive activity) (Suppl. Fig. 9). However, substantial differences between the DGK $\delta-\mathrm{KO}$ and control mice were not observed in any tests (Table 1). 


\subsection{DGK $\delta$-KO mice exhibit compulsive checking of objects}

We next performed the novel object recognition test. As shown in Fig. 1A, the DGK $\delta$-KO mice more frequently returned to the novel and familiar objects, and the numbers of contacts of the DGK $\delta$-KO mice to both objects were significantly increased (approximately 6- and 7-fold increases, respectively) compared to the control mice. Moreover, the time of contact in the DGK $\delta-\mathrm{KO}$ mice to the novel and familiar objects was also greatly augmented (approximately 11- and 12-fold increases, respectively) (Fig. 1B). These results indicate that the $\mathrm{DGK} \delta-\mathrm{KO}$ mice showed irrational contacts to objects. Because ritual-like compulsive checking of objects in OCD model mice were reported (Joel, 2006; Szechtman et al., 2001), these results suggested that the DGK $\delta$-KO mice showed OCD-like behaviors. An increase of novel preference of the DGK $\delta$-KO mice was not detected because the time spent on the novel object/the time spent on both objects and the number of contacts to the novel object/the number of contacts to both objects failed to be significantly different between the DGK $\delta-\mathrm{KO}$ and the control mice (Fig. 1C and D).

\subsection{Brain-specific DGK $\delta$-KO mice buried more marbles than control in marble burying test}

Because the marble burying test is related to compulsive behaviors and is used to analyze an OCD-like phenotype (Broekkamp et al., 1986; Joel, 2006), we carried out this test. In the marble burying test, the DGK $\delta$-KO mice buried markedly more marbles (more than 2-fold increase) than the control mice (Fig. 2). The results further suggest that the DGK $\delta$-KO mice showed OCD-like behaviors.

\subsection{Fluoxetine treatment alleviates OCD-like behaviors in brain-specific DGK $\delta$-KO mice}

A selective serotonin reuptake inhibitor (SSRI), fluoxetine, is utilized as an OCD 
remedy (Joel, 2006; Yadin et al., 1991). Therefore, we analyzed the effects of the SSRI on abnormal behaviors in the novel object recognition test and the marble burying test. Increased number and time of contact to a novel object in the DGK $\delta$-KO mice were significantly alleviated to basal levels by the administration of fluoxetine (Fig. 3A and B). Moreover, the enhanced marble burying in DGK $\delta$-KO mice was also significantly decreased to basal levels $d$ by the administration of the SSRI (Fig. 3C). Taken together, these results further suggest that DGK $\delta$-KO mice exhibited OCD-like behaviors (Table 1).

\subsection{A defect in DGK $\delta$ increases axon/neurite outgrowth in primary cultured cortical}

\section{neurons and Neuro-2a neuroblastoma cells}

To investigate the effects of the brain-specific DGK $\delta$-deficiency on neuronal cell functions, primary cultured cortical neurons were prepared from the DGK $\delta-K O$ mice. We performed quantification of cells that had $0,1,2$, and more than 3 axon/neurites in control and DGK $\delta-\mathrm{KO}$ cortical neurons. As shown in Fig. 4, the percentage of cells that had more than 3 axon/neurites significantly increased (approximately 2.5-fold) in DGK $\delta$-KO neurons, compared to the control cells.

To verify the effects of DGK $\delta$-deficiency on the extension of axon/neurites in primary cultured neuronal cells, we transfected DGK $\delta$-specific siRNA into Neuro-2a neuroblastoma cells and observed axon/neurite extension. We confirmed that the expression levels of the DGK $\delta$ protein were markedly reduced (Fig. 5A). We counted the numbers of cells that had $0,1,2$, and more than 3 axon/neurites in control and DGK $\delta$-knockdown Neuro-2a cells. As observed in DGK $\delta$-deficient neuronal cells (Fig. 4), the percentage of cells that had more than 3 axon/neurites substantially increased (approximately 2.5-fold) in DGK $\delta$-silenced cells compared to control cells (Fig. 5B and C).

Next, we overexpressed DGK $\delta$ in Neuro-2a cells. We performed quantification of 
cells that had $0,1,2$, and more than 3 axon/neurites in AcGFP alone and AcGFP-DGK $\delta$-overexpressed Neuro-2a cells as well. In contrast to DGK $\delta$-knockdown Nuero-2a cells (Fig. 5) and DGK $\delta$-deficient neuronal cells (Fig. 4), the percentage of cells that had more than 3 axon/neurites and no axon/neurites significantly decreased and increased, respectively, in DGK $\delta$-overexpressed cells, compared to control cells (Fig. 6A and B). Taken together, these results strongly suggest that DGK $\delta$ negatively regulates axon/neurites in neuronal cells. 


\section{Discussion}

OCD is a psychiatric affliction with a lifetime prevalence of $1-3 \%$ (Rasmussen and Eisen, 1992; Sasson et al., 1997). The essential features of OCD are recurrent obsessions and compulsions (e.g., doubting, checking and washing) that are time consuming or cause marked distress or significant impairment. For example, compulsive checking interferes with normal everyday functioning because of the many hours of time spent in the performance of checking rituals. OCD checking involves the performance of actions supposedly related to security, orderliness or accuracy, but is characterized by the repeated and excessive re-doing of such rituals. Several neural systems have been implicated in the pathophysiology of OCD. However, the nature of the dysfunction of the neurotransmitter systems postulated to be involved in OCD is still unknown. For obvious reasons, the understanding and treatment of diseases such as OCD must rely heavily on appropriate animal models that closely mimic their behavioral and, if possible, their neural manifestations (Joel, 2006).

It is likely that the abnormal behaviors of the brain-specific DGK $\delta$-KO mice are similar to OCD-like behaviors based on three criteria (Table 1): (1) ritualistic action to objects, (2) enhanced marble burying, and (3) sensitivity to a SSRI, fluoxetine.

(1) Ritualistic action towards objects in OCD model mice was reported (Joel, 2006; Szechtman et al., 2001). Both the number and time of contact in the DGK $\delta-K O$ mice to the novel and familiar objects were greatly increased, suggesting that the KO mice exhibited ritual-like compulsive checking of objects (Fig. 1).

(2) The marble burying test is used to detect an OCD-like phenotype (Broekkamp et al., 1986; Joel, 2006). The DGK $\delta$-KO mice buried markedly more marbles than the control mice (Fig. 2).

(3) Dysregulation of the serotonergic system has been suggested primarily on the basis of the effectiveness of SSRIs in alleviating obsessions and compulsions in patients (Zohar and Insel, 1987) and has received further support from neurobiological, 
pharmacological and more recently genetic data (Murphy et al., 2001; Ozaki et al., 2003). An SSRI, fluoxetine, is generally used as an OCD remedy (Joel, 2006; Yadin et al., 1991). Both increased number/time of contact to a novel object and enhanced marble burying in the DGK $\delta$-KO mice were significantly alleviated by the administration of fluoxetine to basal levels (Fig. 3). The SSRI was significantly effective on only the contact to the novel objects in the novel object test. Because mice, including the DGK $\delta$-KO mice (Fig. 1C and D), generally prefer to a novel object, it is likely that the partial effect of the SSRI on the compulsive checking was preferentially appeared in the contact to a familiar object but not a novel object.

Although SSRIs are currently considered an effective first line treatment for OCD, there are some patients who do not respond to SSRI intervention (Fineberg et al., 2015). Therefore, the deficiency of DGK $\delta$ would provide a model for SSRI-sensitive OCD. SSRIs are also effective in several other psychiatric disorders, including depression, anxiety disorder and social phobia (Argyropoulos et al., 2000; Vaswani et al., 2003). However, the DGK $\delta$-deficient mice did not show abnormal behaviors in the tail suspension test (anti-depressive activity) (Suppl. Fig. 9), the open field test (anxiety abnormalities) (Suppl. Fig. 4), the elevated plus-maze (anxiety abnormality) (Suppl. Fig. 5), or the sociability test (Suppl. Fig. 6). Therefore, it is unlikely that DGK $\delta$ is involved in those psychiatric disorders.

There are several genetic mouse models of OCD (Joel, 2006). Greer and Capecchi reported that mice with disruptions of Hoxb8 show excessive grooming compared to control littermates (Greer and Capecchi, 2002). Chou-Green et al. reported that serotonin receptor $2 \mathrm{c}-\mathrm{KO}$ mice showed increased chewing, but not eating, of non-nutritive clay and a tendency to exhibit increased chewing of a plastic screen (Chou-Green et al., 2003). Berridge et al. found that in addition to hyperactivity such as attention deficit hyperactivity disorder, the dopamine transporter-knockdown mice spent more time than wild-type mice engaged in grooming behavior (Berridge et al., 2005). 
Mice with a genetic deletion of SAP90/PSD95-associated protein 3 exhibited increased anxiety and compulsive grooming behavior leading to facial hair loss and skin lesions (Welch et al., 2007). Those phenotypes are different from those of the DGK $\delta$-deficient mice. However, the etiology of OCD is currently unknown and most likely involves the interaction of multiple genetic and environmental factors (Murphy et al., 2001). Although we cannot deny the possibility that DGK $\delta$ is involved in other psychiatric disorders, the deficiencies of $\mathrm{DGK} \delta$, Hoxb8, serotonin receptor 2c, dopamine transporter, and SAP90/PSD95-associated protein 3 would provide models of different aspects of OCD.

A female patient with a de novo balanced translocation, 46,X,t(X;2)(p11.2;q37)dn was found (Leach et al., 2007). In this patient, the DGK $\delta$ gene is disrupted at $2 q 37$. This patient exhibited seizures. Although a potential seizure phenotype in mutant mice was investigated by a seizure-susceptibility study using PTZ, PTZ-induced seizures were not detected in the DGK $\delta$-KO mice (Suppl. Fig. 3) as described previously (Leach et al., 2007). Mild self-harm such as skin-picking and hair-pulling was observed in the DGK $\delta$-deficient patient (Leach et al., 2007). Interestingly, a relationship between self-harm and OCD was reported (Bejerot et al., 2014; Yaryura-Tobias et al., 1995), suggesting that the patient may have OCD-like disorders.

DGK $\delta$ negatively regulated the extension of long axon/neurite (Figs. 4-6). The results strongly suggest that deficiency of DGK $\delta$ induces OCD-like behavior by enhancing axon/neurite outgrowth. DGK $\delta$ positively regulates growth factor signaling (Crotty et al., 2006). Therefore, DGK $\delta$ deficiency may disturb the growth-differentiation balance and enhance differentiation in neuronal cells. As described above, the SSRI, fluoxetine, attenuated the phenotypes in the DGK $\delta$-deficient mice. Moreover, DGK $\delta$ is highly expressed in the cerebral cortex (Usuki et al., 2015), in which OCD-related serotonin transporter is also abundant (Matsumoto et al., 2010). Therefore, it is possible that the serotonergic system is involved in the phenotypes 
observed in the DGK $\delta$-deficient mice. Physiological responses in serotonin nerve terminals are known to be influenced by changes in protein kinase $\mathrm{C}$ activity, which is inhibited by SSRI (Kramer et al., 1998). Because protein kinase C is activated by DG (Nishizuka, 1992), DGK $\delta$ may affect the serotonergic system through consumption of DG. However, the molecular mechanisms causing the enhanced axon/neurite extension and the OCD-like abnormal behaviors are still unclear. Further investigations are needed to reveal the mechanisms.

Investigations using KO mice have already suggested that DGK $\beta$ (Kakefuda et al., 2010), $\varepsilon$ (Rodriguez De Turco et al., 2001) and $\eta$ (Isozaki et al., 2016) are involved in bipolar disorder, seizure and bipolar disorder, respectively. In the present study, we added DGK $\delta$ to the list of psychiatry-related DGK isozymes. Because OCD is probably a heterogeneous and an etiologically complex disorder, the use of different models may allow investigation of the various aspects and subtypes of OCD. In the present study, we demonstrated that brain-specific DGK $\delta$-KO mice showed OCD-like behaviors. Therefore, the mouse can be a useful OCD model. 


\section{Materials and Methods}

\subsection{Animals}

This study received approval from the Animal Experiment Committee of Chiba University (permission number: 2012-95, 2013-149, 2013-251, 2014-096, and 2014-370) and the Institutional Animal Care and Use Committee of the RIKEN Kobe Branch (Permit Number: AH13-03-65). All procedures relating to animal care and treatment conformed to the animal care guidelines of the committees. All efforts were made to minimize both the suffering and the number of animals used. The animals were housed at $24 \pm 2{ }^{\circ} \mathrm{C}$ under a $12 \mathrm{~h}$ light-dark cycle (lights on from 7:00 to 19:00) with ad libitum access to food and water.

DGK $\delta$-KO animals (Accession No. CDB0660K: http://www2.clst.riken.jp/arg/mutant\%20mice\%20list.html) were generated as described previously (http://www2.clst.riken.jp/arg/Methods.html). Briefly, a targeting construct was prepared by placing LoxP sites flanking exon 9 of DGK $\delta$ (Suppl. Fig. 1A). Embryonic stem cells selected for neomyocin resistance were screened for homologous recombination by PCR across the long and short targeting arms, using primers within and outside of the targeting cassette. For behavioral testing, calmodulin-dependent kinase II $\alpha$ (CaMKII $\alpha)$-Cre positive male; kindly provided by Professor Katsuhiko Mikoshiba through the RIKEN BioResource Center (Tsukuba, Japan) and female mice from heterozygous breeding pairs were mated. $\mathrm{Cre}^{-/-}: 10 \mathrm{xP}^{+/+}$mice were originated from C57BL/6 and CBA backgrounds, and then backcrossed with C57BL/6 mice (Japan SLC, Shizuoka, Japan) for five generations to eliminate any background effects on the observed phenotypes. $\mathrm{Cre}^{-/-}: \operatorname{lox} \mathrm{P}^{+/+}$mice were mated with $\mathrm{cre}^{+/-}: \operatorname{lox} \mathrm{P}^{-/-}$to achieve the brain-specific defect in DGK $\delta$. Thus, $>99 \%$ of $\mathrm{cre}^{+/-}: 10 x \mathrm{P}^{+/+}$mouse's genome should be derived from C57BL/6. Behavioral experiments were performed between 10:00 and 18:00. We used $\mathrm{cre}^{-/-}: \operatorname{lox} \mathrm{P}^{+/+}$(control) littermates as a control group for $\mathrm{cre}^{+/-}: \operatorname{lox}^{+/+}$ (brain-specific DGK $\delta-\mathrm{KO}$ ) mice. 


\subsection{Genotyping}

Genotyping for the loxP gene was carried out by polymerase chain reaction (PCR) using the following primers: Forward primer 5'-TCCTACСТCТСТСТCСАТТCCC-3' and reverse primer 5'-AAGGTGTTGAATAATACTCTGTGAC-3'. PCR conditions were as follows: $94^{\circ} \mathrm{C}$ for $3 \mathrm{~min} ; 32$ cycles of $94^{\circ} \mathrm{C}$ for $30 \mathrm{sec}, 58^{\circ} \mathrm{C}$ for $30 \mathrm{sec}$, and $72^{\circ} \mathrm{C}$ for 2 $\min$; and $72^{\circ} \mathrm{C}$ for $5 \mathrm{~min}$. Genotyping for the cre gene was carried using the following primers: Forward primer 5'-ACGGGAACAGGGCGTTTCGGAGGTGGTTGC-3' and reverse primer 5'-CTAATCGCCATCTTCCAGCACGG-3'. PCR conditions were as follows: $94^{\circ} \mathrm{C}$ for $3 \mathrm{~min} ; 32$ cycles of $94^{\circ} \mathrm{C}$ for $30 \mathrm{sec}, 60^{\circ} \mathrm{C}$ for $30 \mathrm{sec}$, and $72^{\circ} \mathrm{C}$ for $1.5 \mathrm{~min}$; and $72^{\circ} \mathrm{C}$ for $5 \mathrm{~min}$. PCR condition for the cre gene was confirmed using the following primers: Forward primer 5'-TGAGCGAGCTCATCAAGATAATCAGGT-3' and reverse primer 5'-GTTAGCATTGAGCTGCAAGCGCCGTCT-3'.

\subsection{Western blotting}

Western blotting of the brain was performed using the anti-DGK $\delta$ (Sakane et al. 2002) and anti-GFP antibody (sc-9996, Santa Cruz Biotechnology) as previously described (Tsushima et al., 2004).

\subsection{Novel object recognition test}

During habituation, mice (15-20-week-old) were allowed to explore an empty box for 5 min. After habituation, the mice were exposed to the familiar arena with two identical objects placed at an equal distance for $10 \mathrm{~min}$. Ten minutes after the familiar phase, the mice were allowed to explore the open field in the presence of the familiar object and a novel object for $10 \mathrm{~min}$ to test interests to objects and cognitive ability. The novel object was different from the familiar object in shape, color, and texture. The time spent exploring and the numbers of contacts with each object were recorded and measured. 
Novel preferences were calculated as follows: Time spent on the novel object/time spent on both objects and the number of contacts to the novel object/the number of contacts to both objects.

\subsection{Marble burying test}

The cage was filled approximately $3 \mathrm{~cm}$ deep with bedding that was lightly tamped down to make a flat surface, and each mouse (10-20-week-old) was left in the cage for 30 min without marbles. After the habituation, 15 glass marbles were placed on the surface, evenly spaced. The mouse was placed in the cage with the marbles and left for $30 \mathrm{~min}$. The number of marbles that had $50 \%$ of their surface buried with bedding was determined.

\subsection{Fluoxetine treatment}

Fluoxetine was dissolved in $0.9 \%$ saline. Mice (10-21 weeks of age) were injected intraperitoneally with fluoxetine $(10 \mathrm{mg} / \mathrm{kg}, \mathrm{F} 132$, Sigma Aldrich) once a day for six days, and their behaviors were tested before and after the fluoxetine treatment.

\subsection{Primary culture of mouse cortical neurons}

The embryonic mouse cortices were dissociated between embryonic days E13.5 and E14.5 in Opti-MEM (Thermo Fisher Scientific). The cells were seeded onto poly-L-lysine-coated $60-\mathrm{mm}$ dishes with coverslips at a density of $1.5 \times 10^{4}$ cells/dish in Opti-MEM supplemented with $100 \mathrm{U} / \mathrm{ml}$ penicillin/100 $\mu \mathrm{g} / \mathrm{ml}$ streptomycin (Wako Pure Chemical Industries) containing B-27 supplement (Thermo Fisher Scientific).

\subsection{Cell culture and transfection}

Mouse neuroblastoma Neuro-2a cells were maintained in Dulbecco's modified Eagle's medium (D-MEM, Wako Pure Chemical Industries) supplemented with $10 \%$ fetal 
bovine serum (FBS) and $100 \mathrm{U} / \mathrm{ml}$ penicillin $/ 100 \mu \mathrm{g} / \mathrm{ml}$ streptomycin at $37^{\circ} \mathrm{C}$ in an atmosphere containing $5 \% \quad \mathrm{CO}_{2}$. The Neuro-2a cells were seeded in poly-L-lysine-coated $60-\mathrm{mm}$ dishes with coverslips at a density of $2.0 \times 10^{5}$ cells/dish for siRNA transfection and $0.5 \times 10^{5}$ cells/dish for transfection of AcGFP-DGK $\delta$. To silence the expression of mouse DGK $\delta$, the following Stealth RNAi duplexes (Invitrogen) were used: $\quad$ DGK $\delta$-siRNA: 5'-UACUCACAGAGACUGAGGUGCUCCA-3'

5'-UGGAGCACCUCAGUCUCUGUGAGUA-3'; control-siRNA: 5'-UGGCACCUCUGACUCUGUAGAGGUA-3' 5'-UAUCUUUGCAUCCAAGCCAAUGCCA-3'. The duplexes were transfected into Neuro-2a cells by electroporation (at $350 \mathrm{~V}$ and 300 microfarads) using the Gene Pulser XcellTM electroporation system (Bio-Rad Laboratories). The transfected cells were then allowed to grow in D-MEM containing 10\% FBS. The AcGFP-C1 vector or AcGFP-C1-DGK 82 (Sakane et al. 2002) was transiently transfected using Lipofectamine 2000 transfection reagent (Thermo Fisher Scientific) according to the instructions from the manufacturer. Twenty-four hours after transfection, the medium was changed to D-MEM supplemented with $2 \%$ FBS containing $20 \mu \mathrm{M}$ retinoic acid. The cells were observed after $72 \mathrm{~h}$ of treatment with retinoic acid.

\subsection{Confocal laser scanning microscopy}

Cell were fixed with $3.7 \%$ formaldehyde and rinsed with $1 \%$ bovine serum albumin/phosphate-buffered saline (PBS) and incubated with $0.1 \%$ Triton X-100/PBS. The blocking step was performed using $2 \%$ BSA/PBS for $30 \mathrm{~min}$. Anti- $\beta$ III-tubulin antibody (T2200, Sigma Aldrich) and Alexa Fluor 594 conjugated anti-rabbit IgG secondary antibody (A11012, Thermo Fisher Scientific) or FITC conjugated anti-rabbit IgG secondary antibody (sc-2090, Santa Cruz Biotechnology) were incubated for $1 \mathrm{~h}$. The cells were washed with PBS after each step. The coverslips were mounted using 
Vectashield (Vector Laboratories). The cells were examined using inverted confocal laser microscopy (FV1000-D, Olympus).

\subsection{Statistical analysis}

Pairwise comparisons were performed using Student's $t$-test. When comparing more than two groups, one-way ANOVA followed by Tukey's post hoc test was used. Statistical significance was defined as $p \leq 0.05$. 


\section{Acknowledgments}

This work received support from MEXT/JSPS KAKENHI Grant Numbers 22370047 (Grant-in-Aid for Scientific Research (B)), 23116505 (Grant-in-Aid for Scientific Research on Innovative Areas), 25116704 (Grant-in-Aid for Scientific Research on Innovative Areas), 26291017 (Grant-in-Aid for Scientific Research (B)) and 15K14470 (Grant-in-Aid for Challenging Exploratory Research); the Japan Science and Technology Agency (AS221Z00794F, AS231Z00139G, and AS251Z01788Q); the Naito Foundation; the Hamaguchi Foundation for the Advancement of Biochemistry; the Daiichi-Sankyo Foundation of Life Science; the Terumo Life Science Foundation, the Futaba Electronic Memorial Foundation; the Daiwa Securities Health Foundation, the Ono Medical Research Foundation; the Japan Foundation for Applied Enzymology, the Food Science Institute Foundation; the Skylark Food Science Institute; and Asahi Group Foundation (FS). 


\section{References}

Argyropoulos, S.V., Sandford, J.J., Nutt, D.J., 2000. The psychobiology of anxiolytic drug. Part 2: Pharmacological treatments of anxiety. Pharmacol Ther. 88, 213-27.

Bejerot, S., Edman, G., Anckarsater, H., Berglund, G., Gillberg, C., Hofvander, B., Humble, M.B., Mortberg, E., Rastam, M., Stahlberg, O., Frisen, L., 2014. The Brief Obsessive-Compulsive Scale (BOCS): a self-report scale for OCD and obsessive-compulsive related disorders. Nord J Psychiatry. 68, 549-59.

Berridge, K.C., Aldridge, J.W., Houchard, K.R., Zhuang, X., 2005. Sequential super-stereotypy of an instinctive fixed action pattern in hyper-dopaminergic mutant mice: a model of obsessive compulsive disorder and Tourette's. BMC Biol. 3, 4.

Broekkamp, C.L., Rijk, H.W., Joly-Gelouin, D., Lloyd, K.L., 1986. Major tranquillizers can be distinguished from minor tranquillizers on the basis of effects on marble burying and swim-induced grooming in mice. Eur J Pharmacol. 126, 223-9.

Chibalin, A.V., Leng, Y., Vieira, E., Krook, A., Bjornholm, M., Long, Y.C., Kotova, O., Zhong, Z., Sakane, F., Steiler, T., Nylen, C., Wang, J., Laakso, M., Topham, M.K., Gilbert, M., Wallberg-Henriksson, H., Zierath, J.R., 2008. Downregulation of diacylglycerol kinase delta contributes to hyperglycemia-induced insulin resistance. Cell. 132, 375-86.

Chou-Green, J.M., Holscher, T.D., Dallman, M.F., Akana, S.F., 2003. Compulsive behavior in the 5-HT2C receptor knockout mouse. Physiol Behav. 78, 641-9.

Crotty, T., Cai, J., Sakane, F., Taketomi, A., Prescott, S.M., Topham, M.K., 2006. Diacylglycerol kinase $\delta$ regulates protein kinase $\mathrm{C}$ and epidermal growth factor receptor signaling. Proc. Natl. Acad. Sci. U S A. 103, 15485-15490.

English, D., 1996. Phosphatidic acid: a lipid messenger involved in intracellular and extracellular signalling. Cell Signal. 8, 341-7.

Exton, J.H., 1994. Phosphatidylcholine breakdown and signal transduction. Biochim Biophys Acta. 1212, 26-42.

Fineberg, N.A., Reghunandanan, S., Simpson, H.B., Phillips, K.A., Richter, M.A., Matthews, K., Stein, D.J., Sareen, J., Brown, A., Sookman, D., 2015. Obsessive-compulsive disorder (OCD): Practical strategies for pharmacological 
and somatic treatment in adults. Psychiatry Res. 227, 114-25.

Goto, K., Nakano, T., Hozumi, Y., 2006. Diacylglycerol kinase and animal models: the pathophysiological roles in the brain and heart. Adv Enzyme Regul. 46, 192-202.

Greer, J.M., Capecchi, M.R., 2002. Hoxb8 is required for normal grooming behavior in mice. Neuron. 33, 23-34.

Harada, B.T., Knight, M.J., Imai, S., Qiao, F., Ramachander, R., Sawaya, M.R., Gingery, M., Sakane, F., Bowie, J.U., 2008. Regulation of enzyme localization by polymerization: polymer formation by the SAM domain of diacylglycerol kinase $\delta 1$. Structure. $16,380-7$.

Hodgkin, M.N., Pettitt, T.R., Martin, A., Michell, R.H., Pemberton, A.J., Wakelam, M.J., 1998. Diacylglycerols and phosphatidates: which molecular species are intracellular messengers? Trends Biochem Sci. 23, 200-4.

Imai, S., Sakane, F., Kanoh, H., 2002. Phorbol ester-regulated oligomerization of diacylglycerol kinase $\delta$ linked to its phosphorylation and translocation. J. Biol. Chem. 277, 35323-35332.

Imai, S., Kai, M., Yamada, K., Kanoh, H., Sakane, F., 2004. The plasma membrane translocation of diacylglycerol kinase $\delta 1$ is negatively regulated by conventional protein kinase C-dependent phosphorylation at Ser-22 and Ser-26 within the pleckstrin homology domain. Biochem. J. 382, 957-966.

Imai, S., Kai, M., Yasuda, S., Kanoh, H., Sakane, F., 2005. Identification and characterization of a novel human type II diacylglycerol kinase, DGK kappa. J Biol Chem. 280, 39870-81.

Isozaki, T., Komenoi, S., Lu, Q., Usuki, T., Tomokata, S., Matsutomo, D., Sakai, H., Bando, K., Kiyonari, H., Sakane, F., 2016. Deficiency of diacylglycerol kinase eta induces lithium-sensitive mania-like behavior. J Neurochem. in press, (DOI: 10.1111/jnc.13661).

Joel, D., 2006. Current animal models of obsessive compulsive disorder: a critical review. Prog Neuropsychopharmacol Biol Psychiatry. 30, 374-88.

Kakefuda, K., Oyagi, A., Ishisaka, M., Tsuruma, K., Shimazawa, M., Yokota, K., Shirai, Y., Horie, K., Saito, N., Takeda, J., Hara, H., 2010. Diacylglycerol kinase $\beta$ knockout mice exhibit lithium-sensitive behavioral abnormalities. PloS one. 5, e13447. 
Klauck, T.M., Xu, X., Mousseau, B., Jaken, S., 1996. Cloning and characterization of a glucocorticoid-induced diacylglycerol kinase. J Biol Chem. 271, 19781-8.

Knight, M.J., Joubert, M.K., Plotkowski, M.L., Kropat, J., Gingery, M., Sakane, F., Merchant, S.S., Bowie, J.U., 2010. Zinc Binding Drives Sheet Formation by the SAM Domain of Diacylglycerol Kinase $\delta$. Biochemistry. 49, 9667-9676.

Kramer, H.K., Poblete, J.C., Azmitia, E.C., 1998. Characterization of the translocation of protein kinase $\mathrm{C}$ (PKC) by 3,4-methylenedioxymethamphetamine (MDMA/ecstasy) in synaptosomes: evidence for a presynaptic localization involving the serotonin transporter (SERT). Neuropsychopharmacology. 19, $265-77$.

Leach, N.T., Sun, Y., Michaud, S., Zheng, Y., Ligon, K.L., Ligon, A.H., Sander, T., Korf, B.R., Lu, W., Harris, D.J., Gusella, J.F., Maas, R.L., Quade, B.J., Cole, A.J., Kelz, M.B., Morton, C.C., 2007. Disruption of diacylglycerol kinase delta (DGKD) associated with seizures in humans and mice. Am. J. Hum. Genet. 80, 792-799.

Matsumoto, R., Ichise, M., Ito, H., Ando, T., Takahashi, H., Ikoma, Y., Kosaka, J., Arakawa, R., Fujimura, Y., Ota, M., Takano, A., Fukui, K., Nakayama, K., Suhara, T., 2010. Reduced serotonin transporter binding in the insular cortex in patients with obsessive-compulsive disorder: a [11C]DASB PET study. Neuroimage. 49, 121-6.

Merida, I., Avila-Flores, A., Merino, E., 2008. Diacylglycerol kinases: at the hub of cell signalling. Biochem J. 409, 1-18.

Miele, C., Paturzo, F., Teperino, R., Sakane, F., Fiory, F., Oriente, F., Ungaro, P., Valentino, R., Beguinot, F., Formisano, P., 2007. Glucose regulates diacylglycerol intracellular levels and protein kinase $\mathrm{C}$ activity by modulating diacylglycerol-kinase subcellular localization. J. Biol. Chem. 282, 31835-31843.

Murakami, T., Sakane, F., Imai, S., Houkin, K., Kanoh, H., 2003. Identification and characterization of two splice variants of human diacylglycerol kinase eta. J Biol Chem. 278, 34364-72.

Murphy, D.L., Li, Q., Engel, S., Wichems, C., Andrews, A., Lesch, K.P., Uhl, G., 2001. Genetic perspectives on the serotonin transporter. Brain Res Bull. 56, 487-94.

Nishizuka, Y., 1992. Intracellular signaling by hydrolysis of phospholipids and activation of protein kinase C. Science. 258, 607-614. 
Ozaki, N., Goldman, D., Kaye, W.H., Plotnicov, K., Greenberg, B.D., Lappalainen, J., Rudnick, G., Murphy, D.L., 2003. Serotonin transporter missense mutation associated with a complex neuropsychiatric phenotype. Mol Psychiatry. 8, 933-6.

Rasmussen, S.A., Eisen, J.L., 1992. The epidemiology and clinical features of obsessive compulsive disorder. Psychiatr Clin North Am. 15, 743-58.

Rodriguez De Turco, E.B., Tang, W., Topham, M.K., Sakane, F., Marcheselli, V.L., Chen, C., Taketomi, A., Prescott, S.M., Bazan, N.G., 2001. Diacylglycerol kinase $\varepsilon$ regulates seizure susceptibility and long-term potentiation through arachidonoyl- inositol lipid signaling. Proc. Natl. Acad. Sci. USA. 98, 4740-4745.

Sakai, H., Sakane, F., 2012. Recent progress on type II diacylglycerol kinases: the physiological functions of diacylglycerol kinase delta, eta and kappa and their involvement in disease. J Biochem. 152, 397-406.

Sakai, H., Kado, S., Taketomi, A., Sakane, F., 2014. Diacylglycerol kinase $\delta$ phosphorylates phosphatidylcholine-specific phospholipase C-dependent, palmitic acid-containing diacylglycerol species in response to high glucose levels. J Biol Chem. 289, 26607-17.

Sakane, F., Imai, S., Kai, M., Wada, I., Kanoh, H., 1996. Molecular cloning of a novel diacylglycerol kinase isozyme with a pleckstrin homology domain and a C-terminal tail similar to those of the EPH family of protein tyrosine kinase. J. Biol. Chem. 271, 8394-8401.

Sakane, F., Imai, S., Yamada, K., Murakami, T., Tsushima, S., Kanoh, H., 2002. Alternative splicing of the human diacylglycerol kinase $\delta$ gene generates two isoforms differing in their expression patterns and in regulatory functions. J. Biol. Chem. 277, 43519-43526.

Sakane, F., Imai, S., Kai, M., Yasuda, S., Kanoh, H., 2007. Diacylglycerol kinases: why so many of them? Biochim Biophys Acta. 1771, 793-806.

Sasson, Y., Zohar, J., Chopra, M., Lustig, M., Iancu, I., Hendler, T., 1997. Epidemiology of obsessive-compulsive disorder: a world view. J Clin Psychiatry. 58 Suppl 12, 7-10.

Shionoya, T., Usuki, T., Komenoi, S., Isozaki, T., Sakai, H., Sakane, F., 2015. Distinct Expression and Localization of the Type II Diacylglycerol Kinase Isozymes $\delta, \eta$ 
and $\kappa$ in the Mouse Reproductive Organs. BMC Dev. Biol. 15, 6.

Szechtman, H., Eckert, M.J., Tse, W.S., Boersma, J.T., Bonura, C.A., McClelland, J.Z., Culver, K.E., Eilam, D., 2001. Compulsive checking behavior of quinpirole-sensitized rats as an animal model of Obsessive-Compulsive Disorder(OCD): form and control. BMC Neurosci. 2, 4.

Takeuchi, M., Sakiyama, S., Usuki, T., Sakai, H., Sakane, F., 2012. Diacylglycerol kinase $\delta 1$ transiently translocates to the plasma membrane in response to high glucose. Biochim. Biophys. Acta - Mol. Cell Res. 1823, 2210-2216.

Topham, M.K., Epand, R.M., 2009. Mammalian diacylglycerol kinases: molecular interactions and biological functions of selected isoforms. Biochim Biophys Acta. 1790, 416-24.

Tsushima, S., Kai, M., Yamada, K., Imai, S., Houkin, K., Kanoh, H., Sakane, F., 2004. Diacylglycerol kinase $\gamma$ serves as an upstream suppressor of Rac1 and lamellipodium formation. J. Biol. Chem. 279, 28603-28613.

Usuki, T., Sakai, H., Shionoya, T., Sato, N., Sakane, F., 2015. Expression and localization of type II diacylglycerol kinase isozymes delta and eta in the developing mouse brain. J. Histochem. Cytochem. 63, 57-68.

Vaswani, M., Linda, F.K., Ramesh, S., 2003. Role of selective serotonin reuptake inhibitors in psychiatric disorders: a comprehensive review. Prog Neuropsychopharmacol Biol Psychiatry. 27, 85-102.

Welch, J.M., Lu, J., Rodriguiz, R.M., Trotta, N.C., Peca, J., Ding, J.D., Feliciano, C., Chen, M., Adams, J.P., Luo, J., Dudek, S.M., Weinberg, R.J., Calakos, N., Wetsel, W.C., Feng, G., 2007. Cortico-striatal synaptic defects and OCD-like behaviours in Sapap3-mutant mice. Nature. 448, 894-900.

Yadin, E., Friedman, E., Bridger, W.H., 1991. Spontaneous alternation behavior: an animal model for obsessive-compulsive disorder? Pharmacol Biochem Behav. 40, 311-5.

Yaryura-Tobias, J.A., Neziroglu, F.A., Kaplan, S., 1995. Self-mutilation, anorexia, and dysmenorrhea in obsessive compulsive disorder. Int J Eat Disord. 17, 33-8.

Zohar, J., Insel, T.R., 1987. Obsessive-compulsive disorder: psychobiological approaches to diagnosis, treatment, and pathophysiology. Biol Psychiatry. 22, 667-87. 
Table 1. Summary of the behavioral analyses of brain-specific DGK $\delta$-KO mice.

\begin{tabular}{|c|c|c|c|c|c|}
\hline Behavioral analysis & Subject & & 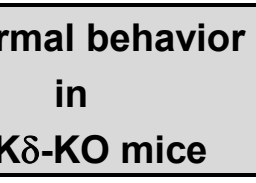 & \multicolumn{2}{|c|}{$\begin{array}{l}\text { Fluoxetine } \\
\text { treatment }\end{array}$} \\
\hline $\begin{array}{c}\text { Seizure after PTZ } \\
\text { intraperitoneal injection }\end{array}$ & Seizure susceptibility & - & Suppl. Fig. 3 & \multirow{8}{*}{\multicolumn{2}{|c|}{ N.D. }} \\
\hline Open field test & Anxiety, activity & - & Suppl. Fig. 4 & & \\
\hline Elevated plus-maze test & Anxiety & - & Suppl. Fig. 5 & & \\
\hline Sociability test & Sociality & - & Suppl. Fig. 6 & & \\
\hline Barns maze test & Learning, Memory & - & Suppl. Fig. 7 & & \\
\hline Cotton bud biting test & Aggression & - & Suppl. Fig. 8 & & \\
\hline Tail-suspension test & Depression & - & Suppl. Fig. 9 & & \\
\hline \multirow{2}{*}{$\begin{array}{c}\text { Novel object recognition } \\
\text { test } \\
\end{array}$} & Cognitive ability & - & Fig. 1 & & \\
\hline & \multirow{2}{*}{$\begin{array}{l}\text { Obsessive-compulsive } \\
\text { disorder }\end{array}$} & + & Fig. 1 & Effective & \multirow{2}{*}{ Fig. 3} \\
\hline Marble burying test & & + & Fig. 2 & Effective & \\
\hline
\end{tabular}

-: abnormal behavior was not observed, +: abnormal behavior was observed, N.D.: not determined. 


\section{Figure legends}

Fig. 1. Contacts with objects increase in novel object recognition test in brain-specific DGK $\delta$-KO mice.

Mice were exposed to one familiar object and one novel object after the familiar phase. (A, B) The number of contacts (A) and the time spent (B) on both objects during the test session were greatly increased in brain-specific DGK $\delta$-KO mice. (C, D) The recognition ability calculated from the number of contacts (C) and time spent (D) was normal in DGK $\delta$-KO mice. Control $\left(\operatorname{cre}^{-/-}: \operatorname{lox} \mathrm{P}^{+/+}\right), n=10$; DGK $\delta-\mathrm{KO}\left(\mathrm{cre}^{+/-}: \operatorname{loxP}^{+/+}\right)$, $n=10$. Data are shown as the mean \pm SEM. ${ }^{*} P<0.05, * * P<0.01$.

Fig. 2. Brain-specific DGK $\delta$-KO mice buried more marbles than control mice during the marble burying test.

(A) Marble distribution 30 minutes after a control (left) or a brain-specific DGK $\delta$-KO (right) mouse was placed in the cage. (B) The graph shows the percentage of the marbles that had $50 \%$ of their surface buried with bedding at 10 min during the marble burying test. Control $\left(\mathrm{cre}^{-/-}: \operatorname{lox} \mathrm{P}^{+/+}\right), n=18$; DGK $\delta-\mathrm{KO}\left(\mathrm{cre}^{+/-}: \operatorname{lox} \mathrm{P}^{+/+}\right), n=18$. Data are shown as mean \pm SEM. ${ }^{* * *} P<0.005$.

Fig. 3. Fluoxetine treatment alleviates obsessive-compulsive disorder-like behavior in brain-specific DGK $\delta$-KO mice.

(A, B) Daily fluoxetine treatment over six days reduced (A) the number of contacts and

(B) the time spent on objects in the novel object recognition test of brain-specific DGK $\delta$-KO mice. (C) Given over 6 days, fluoxetine reduced the number of buried marbles in DGK $\delta$-KO mice in the marble burying test at $10 \mathrm{~min}$. Control $\left(\mathrm{cre}^{-/-}: \operatorname{loxP}^{+/ t}\right)$, $n=8 ;$ DGK $\delta-\mathrm{KO}\left(\mathrm{cre}^{+/-}: \operatorname{lox}^{+/+}\right), n=8$. Data are shown as the mean \pm SEM. $* P<0.05$, $* * * P<0.005$. 
Fig. 4. A defect in DGK $\delta$ increases neurite outgrowth in primary cortical neurons.

(A) Cortical neurons from E13.5 mouse embryos were cultured, and $\beta$ III-tubulin was stained. (B) Quantification of cells that had 0, 1, 2, and more than 3 axon/neurites in control or DGK $\delta$-KO cortical neurons. The percentage of cells that had more than 3 axon/neurites increased in DGK $\delta$-KO neurons. Three independent experiments were performed. Scale bars: $50 \mu \mathrm{m}$. Data are shown as the mean \pm SD. ${ }^{* *} P<0.01$.

\section{Fig. 5. A defect in DGK $\delta$ increases neurite outgrowth in Neuro-2a cells.}

(A) Western blot analysis using anti-GFP antibody demonstrating an efficient decrease in protein levels of DGK $\delta$ after siRNA knockdown in Neuro-2a cells. The relative intensity of each band is shown below. (B) Confocal images of cells stained for $\beta$ III-tubulin. (C) Quantification of cells that had 0, 1, 2, and more than 3 axon/neurites in control or DGK $\delta$-knockdown (KD) Neuro-2a cells. The percentage of cells that had more than 3 axon/neurites increased in DGK $\delta$-KD Neuro-2a cells. Three independent experiments were performed. Scale bars: $50 \mu \mathrm{m}$. Data are shown as the mean $\pm \mathrm{SD}$. $* P<0.05$.

Fig. 6. Overexpression of DGK $\delta$ inhibits neurite outgrowth in Neuro-2a cells.

(A) The AcGFP vector or AcGFP-DGK $\delta 2$ was transfected and $\beta$ III-tubulin was stained in Neuro-2a cells. DGK $\delta$ was located in the vesicles of Neuro-2a cells. (B) Quantification of cells that had 0,1,2, and more than 3 axon/neurites in AcGFP vectoror AcGFP-DGK82-overexpressed Neuro-2a cells. The percentage of cells with no axon/neurites was increased, and the percentage of cells with more than 3 axon/neurites decreased in DGK $\delta$-overexpressed Neuro-2a cells. Three independent experiments were performed. Scale bars: $50 \mathrm{~mm}$. Data are shown as the mean $\pm \mathrm{SD}$. ${ }^{*} P<0.05$. 


\section{Figure 1}
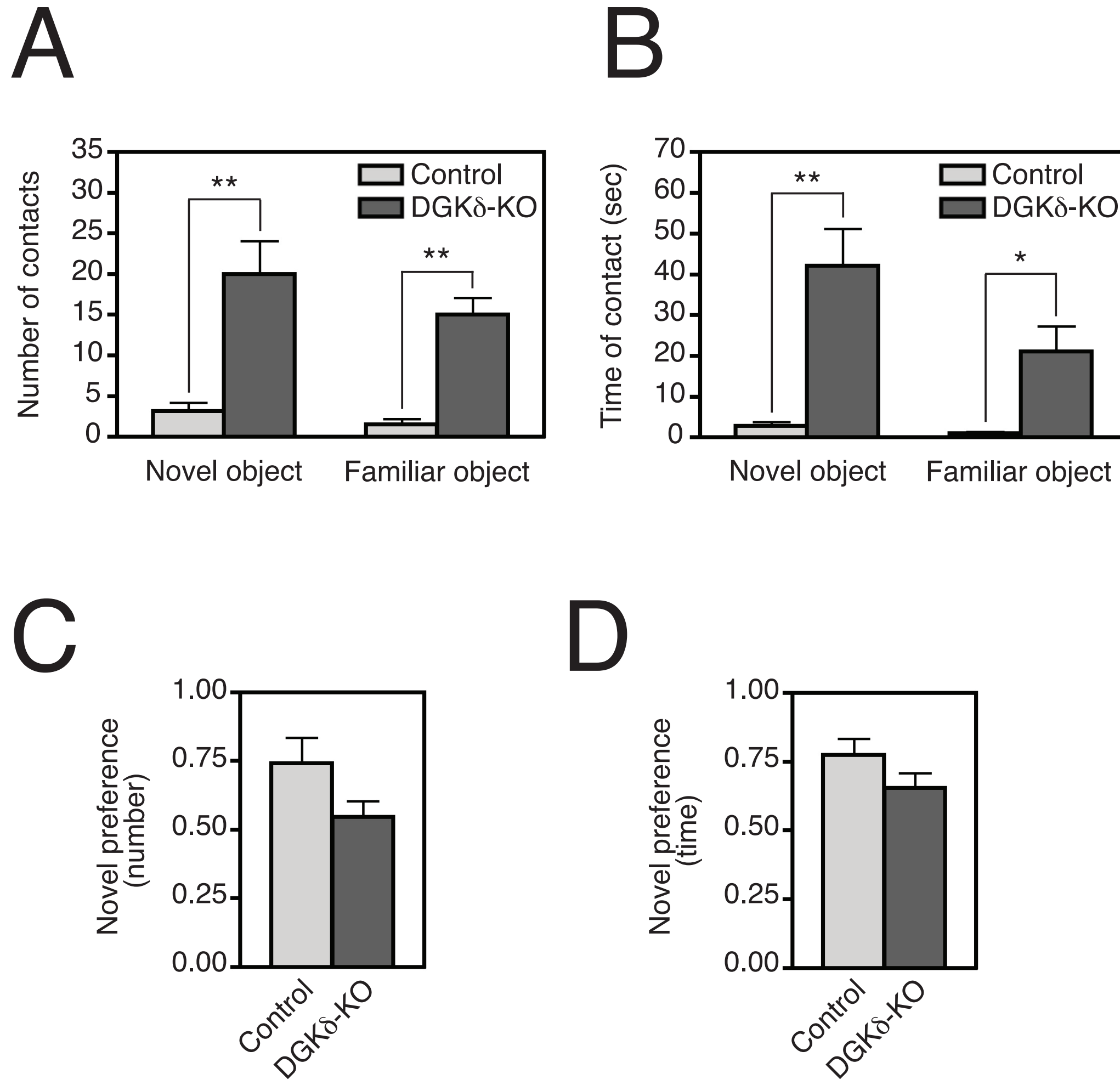


\section{Figure 2}

Control

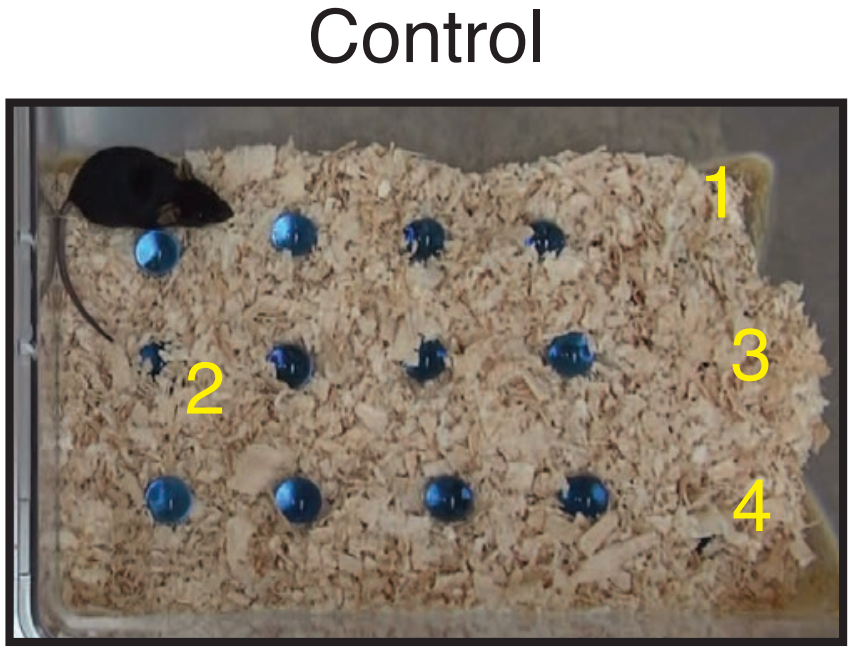

A

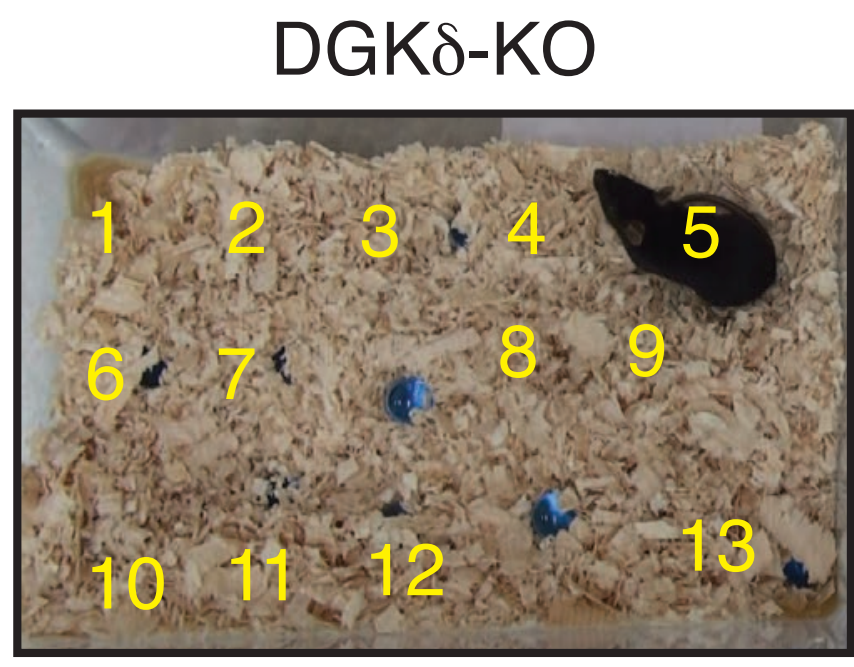

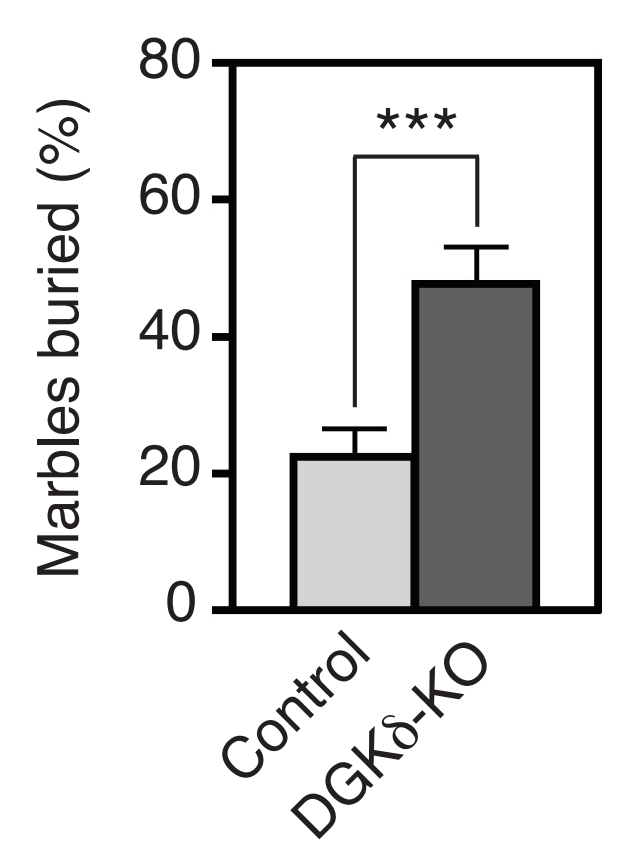

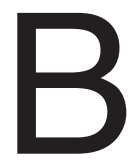




\section{Figure 3}

\section{A}

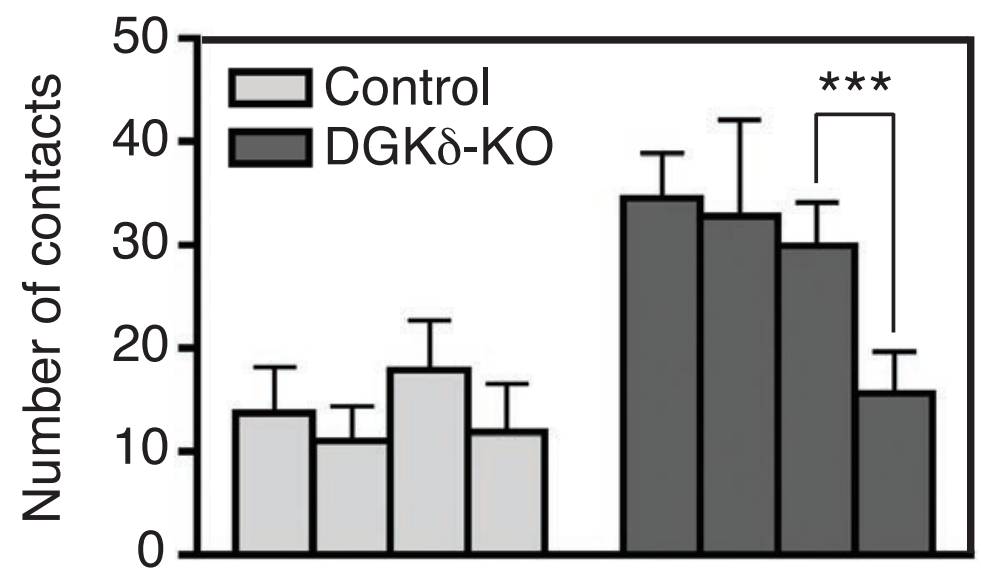

Fluoxetine

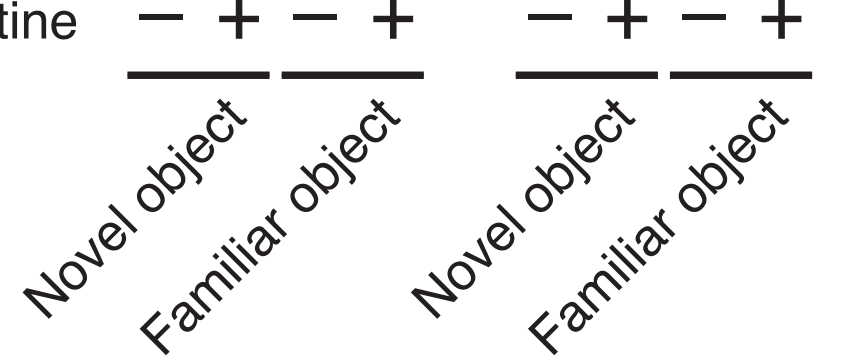

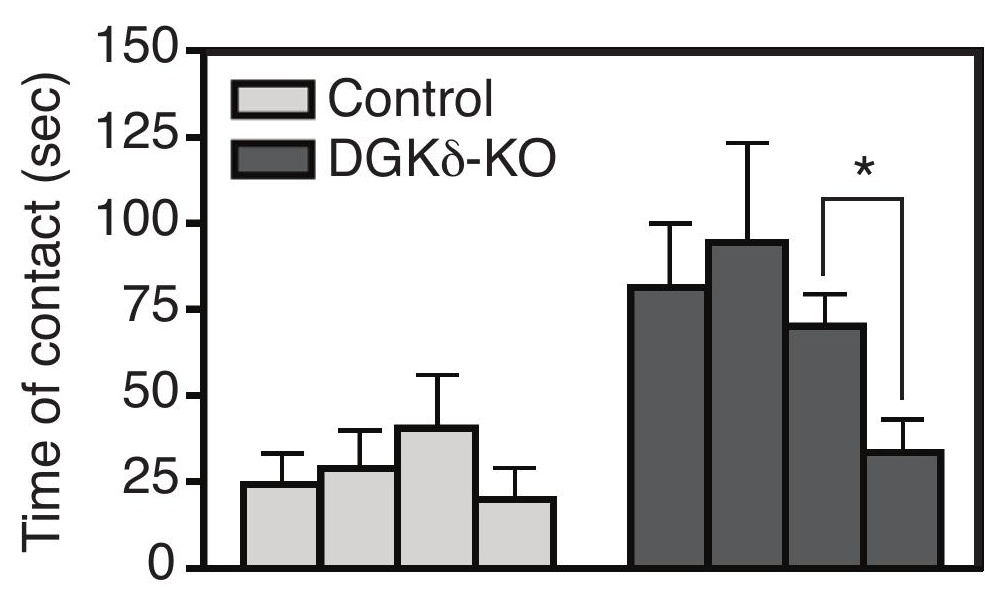

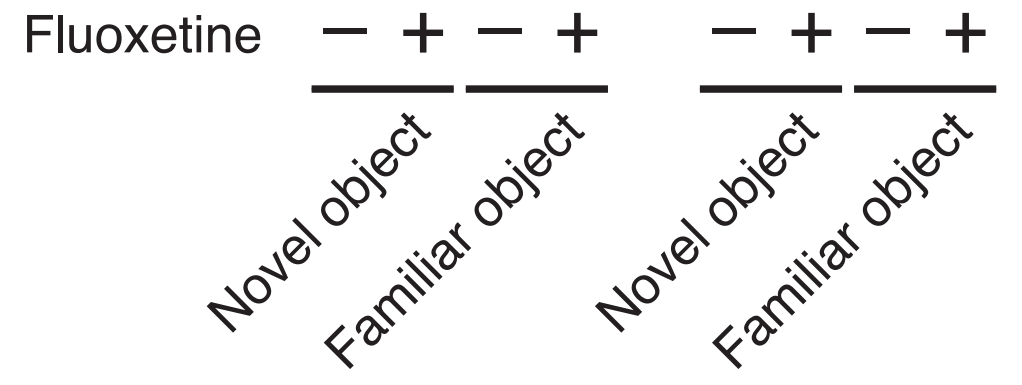

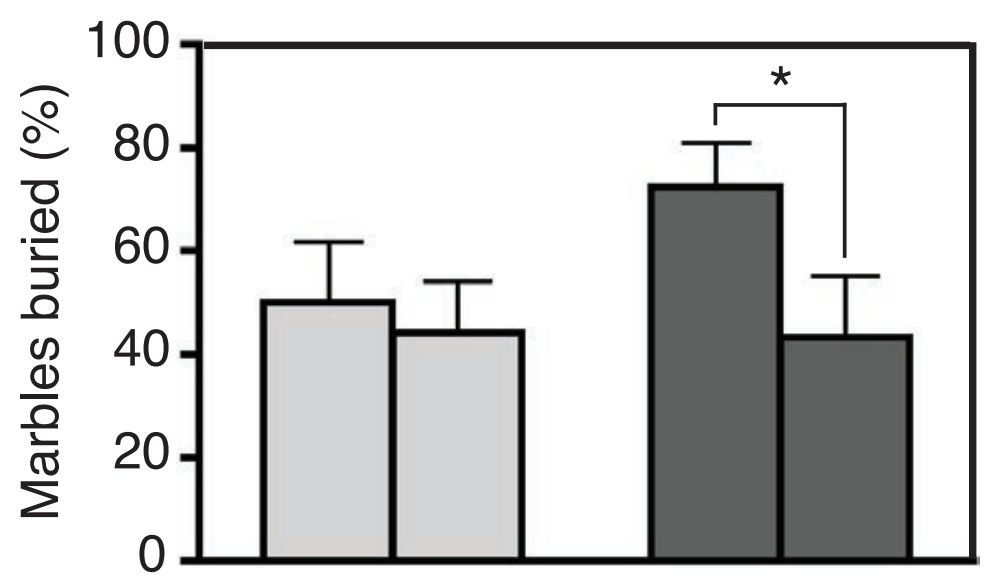

Fluoxetine

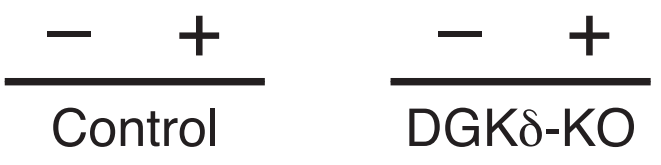




\section{Figure 4}

A
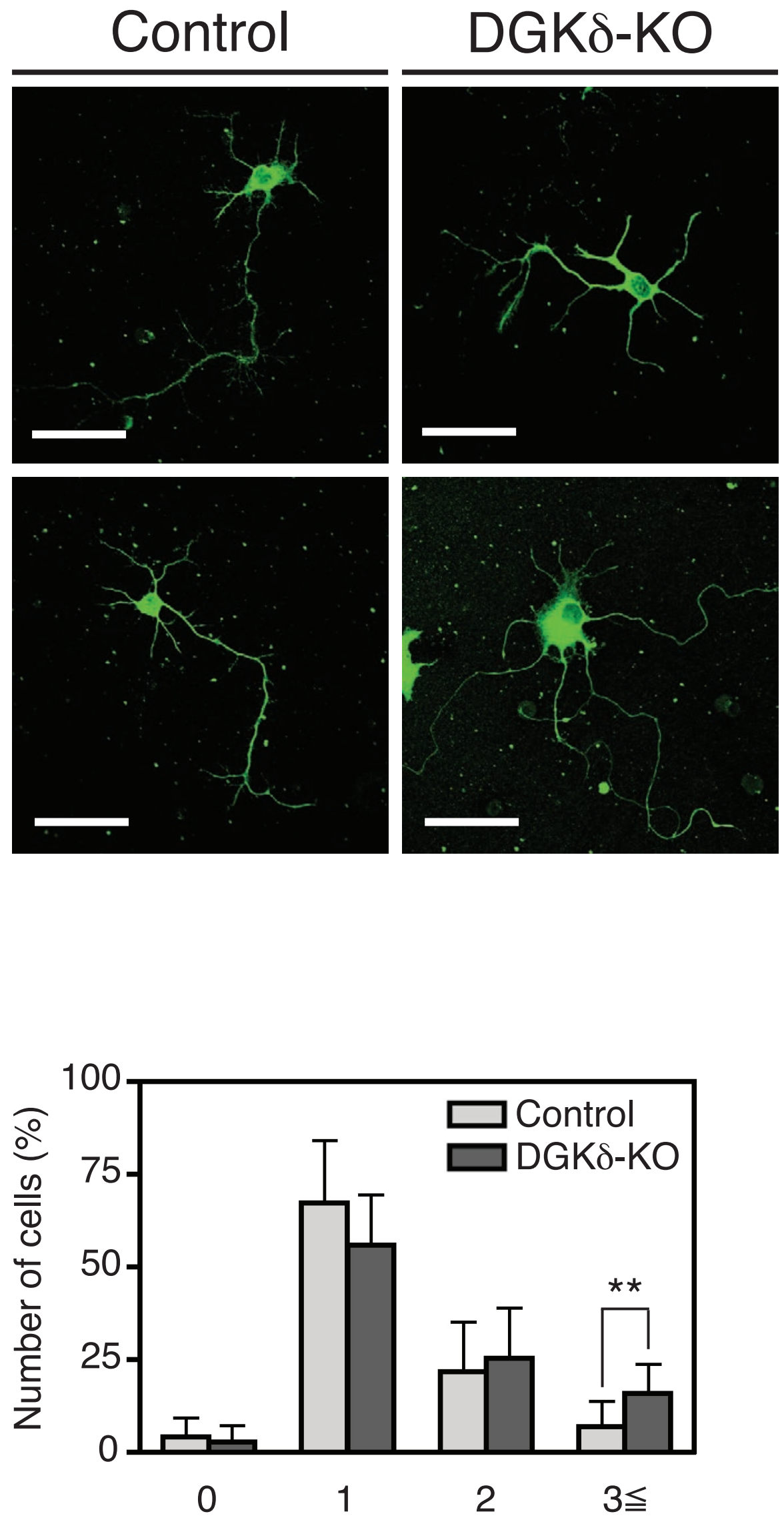

Number of neurites 


\section{Figure 5}

A

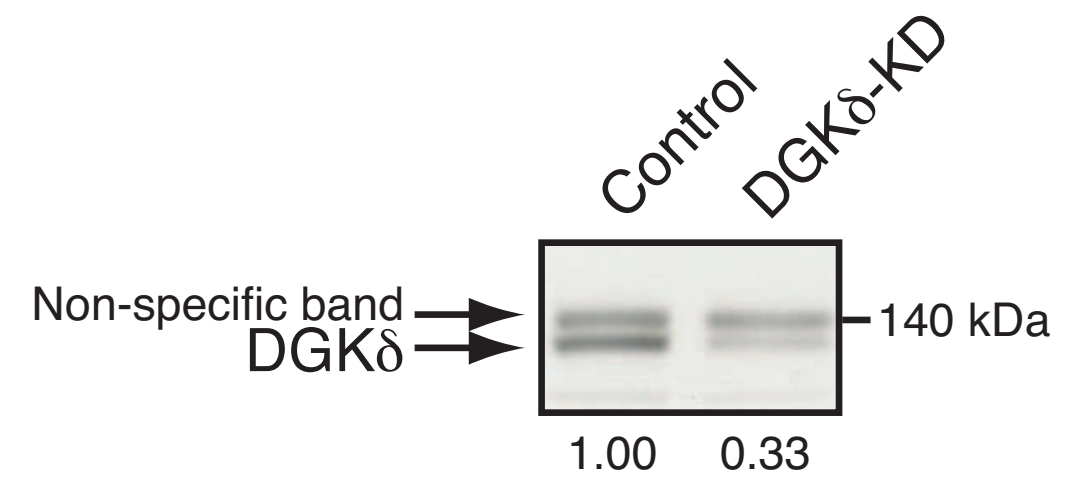

B
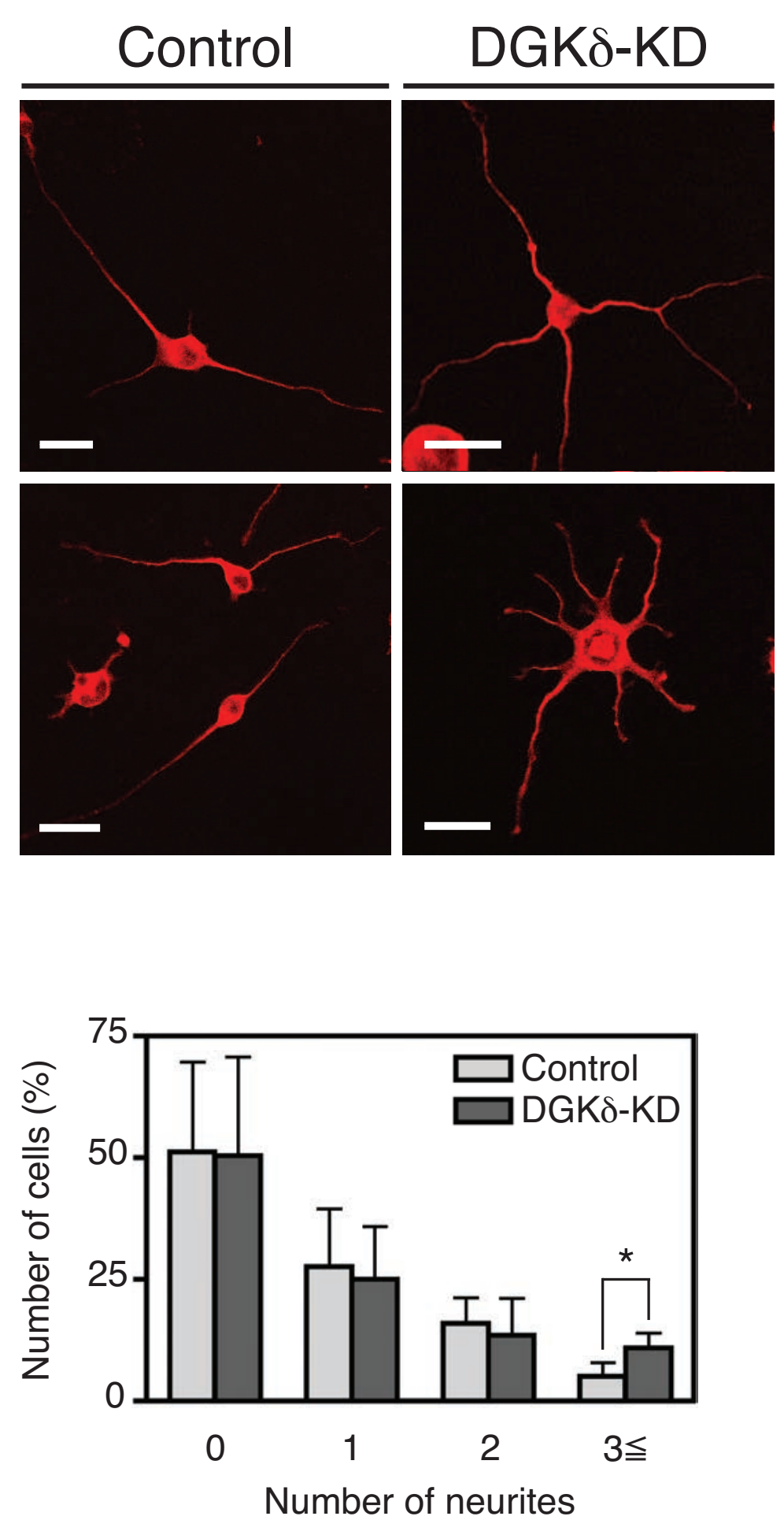
A

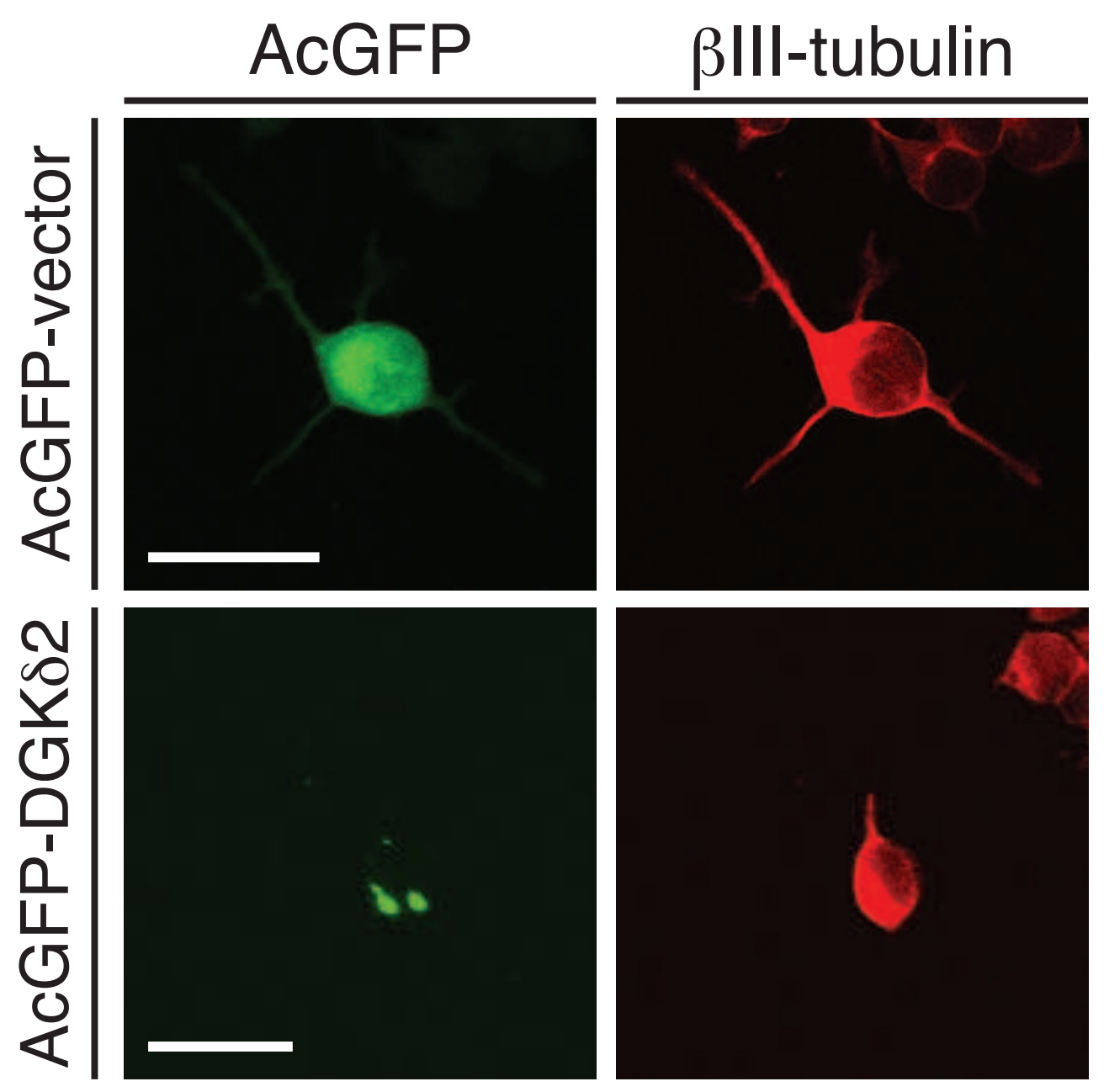

$\beta$ III-tubulin
Merge
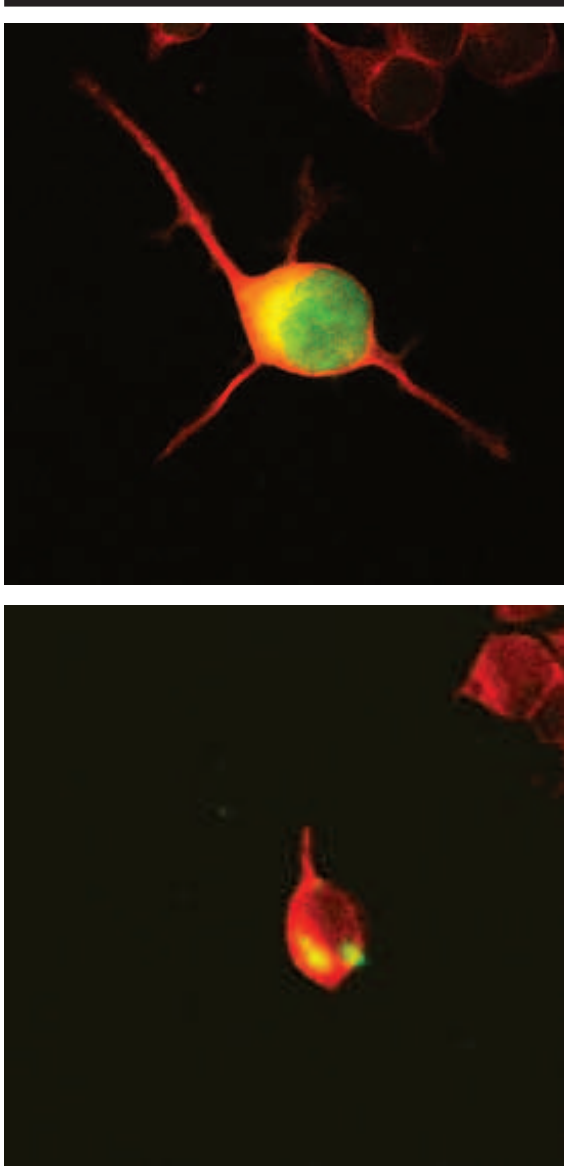

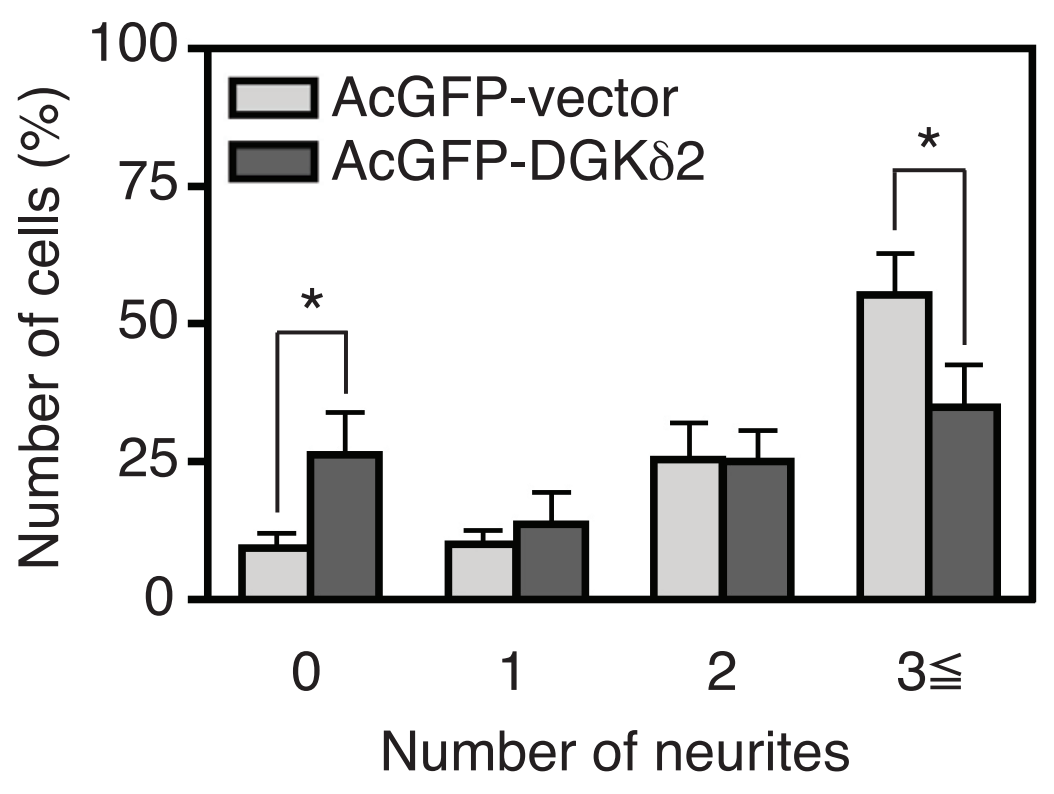

